\title{
Misterio de Cristo, historia de la Salvación, cristocentrismo
}

\section{LA TEOLOGÍA Y EL MISTERIO DE CRISTO}

La concepción paulina del «misterio» es del máximo interés, tanto por lo que en sí encierra cuanto por las consecuencias que de ella se derivan.

Dieciocho veces hace alusión san Pablo al «misterio» en sus cartas. Y aun cuando los especialistas no se han puesto de acuerdo todavía en todos sus matices - al querer determinar el contenido de esa palabra en el Apóstol- sí han llegado a algunas conclusiones muy significativas, como la de que «misterio» en san Pablo es el plan de la Salvación que Dios mantuvo oculto desde la eternidad, y que el mismo Dios reveló y proclamó más tarde en Cristo. Y es que, en todas las fórmulas paulinas, el «misterio» de Dios es Cristo. Y Cristo Salvador. Por lo que categóricamente pudo afirmar san Agustín: «El misterio de Dios no es otra cosa que Cristo, en el que era preciso vivificar a cuantos habían muerto en Adán»" .

Teológicamente hablando, solamente hay un misterio formal: Dios. Dios que, en su incomprensibilidad por la que es Dios, «se nos da como lejanía y horizonte en los que se mueve nuestra existencia; como el punto que se encuentra de manera asintótica en el infinito, y hacia el cual se mueve el pluralismo de las realidades finitas; como único punto unificante del que podemos disponer; pero Dios que, permaneciendo así, se nos entrega en contacto inmediato, con lo cual él mismo viene a ser la realidad más íntima de nuestra existencia» ${ }^{2}$. Autocomunicación y autodonación de Dios al hombre que, sin eliminar el misterio, nos lo hace más entrañablemente amable y más amorosa-

1. San Agustín, Epist. 187, ca. 11, n. 34.

2. VARIOS, Sacramentum mundi: Enciclopedia teológica, vol. IV, col. 715. Editorial Herder, Barcelona 1973. 
mente experimentable, justamente por su afirmación en el amor; pues, en definitiva, solamente él puede dejar intacto al otro en cuanto tal -al Dios incomprensible-, y entregándose libremente al hombre, del hombre hace una realidad autónoma y distinta de él. Que Dios es el Amor, y todo en la vida es para nosotros como una cadena de afectos del amor, en su infinito poder. De donde - escribe Scheeben - aquel único misterio formal de Dios, que es Dios mismo, viene dado en todo aquello que la dogmática cristiana proclama como misterios del cristianismo ${ }^{3}$. Misterios del cristianismo que se nos entraron por las puertas del mundo centrados en el misterio de Cristo, que es el misterio del reino de Dios.

Íntimamente concatenada con la existencia de aquel misterio de Dios y exigida por aquella su autodonación al hombre -en el libre y amoroso proceder de Dios respecto al hombre - viene la relativa necesidad y la muy necesaria conveniencia de la Revelación ${ }^{4}$. Y esa Revelación nos aporta el dato más íntimamente divino, más cordial y menos ininteligible del misterio, cuando Dios no se contenta con decirnos de sí mismo por medio de los hombres, sino que se constituye Él mismo en la palabra humana de la revelación, revelándose a sí mismo. Que «habiendo Dios hablado antaño, en muchas ocasiones y de muchos modos, a nuestros padres por medio de los profetas, últimamente nos habló a nosotros por su Hijo» (Hebr 1,1-2). Revelación de Dios en Cristo, que es abrirse Dios históricamente al mundo, y darse a sí mismo en el misterio de Cristo.

Pero al acercarse los hombres de cada época a la luz de este misterio, lo han hecho basados en unas categorías y con unas preocupaciones que - de antemano- les habían ofrecido el contexto espiritual, sociológico y económico del tiempo en que vivieron. De donde brotaron nuevos y diferentes esclarecimientos del misterio de Cristo, que - en los últimos tiempos- son de innegable luz renovadora para el hombre, para la vida, para la cultura, para la religión y para la historia misma. Todo ello, en ese volver de la teología -en y para su rejuvenecimiento- a las fuentes de la Revelación, como son la Escritura, la Tradición y la Liturgia. Y a fe que la Revelación, cuyo memorial son las sagradas Escrituras - nos subraya al respecto Congar - nos ha enseñado que dichas Escrituras no son ni un código de leyes, ni un catecismo de verdades, ni una lista de proposiciones, sino «una historia de lo que Dios ha hecho en unas vidas de hombres a favor del conjunto de la humanidad, con vistas a

3. SCHEebEn, M.J., Los misterios del cristianismo, cap. 1, p. 4.- 3. ${ }^{a}$ edición. Herder, Barcelona 1960. Traducción del alemán por Antonio Sancho.

4. Denzinger, n. 1786. Cfr. también Vaticano II, Constitución dogmática Dei Verbum, sobre la divina Revelación, nn. 2-6. 
realizar en ésta un determinado designio de salvación. Historia que está dirigida a un término, que esclarece y da sentido a todas sus etapas» ${ }^{5}$.

Por su parte, la vuelta a la Patrística - que significa fidelidad a una época lejana, pero muy rica en contenido y dimensiones teológicas - ha sido, sin duda, un determinante decisivo para ese reencuentro de Dios en y por Cristo, haciéndose así la Teología cristocéntrica. Porque «toda esta historia - señala el mismo Congar - tiene un centro en el hecho de que Jesucristo, en quien lo que nosotros esperamos ha venido ya a nosotros, como en su principio o en su germen. Por eso nuestra predicación y nuestra catequesis, redescubriendo -también- el espíritu de la liturgia, y siguiendo su mismo movimiento, se han hecho cristológicas e históricas, se han centrado en el misterio cristiano y en el misterio pascual, que es como el corazón de todo el misterio cristiano» ${ }^{6}$.

Historia de la Salvación, misterio de Cristo, Economía salvífica o Cristocentrismo que de la mano nos lleva a la Cristología, y de la Cristología al amplio campo de la teología, sin que aquí entremos a pormenorizar sobre cada uno de esos temas teológicos, de los que hay fuentes muy bien documentadas ${ }^{7}$. Aunque sí habremos de subrayar cómo la Teología clásica se ha visto problematizada por la exégesis moderna, justamente en ese volver a las fuentes bíblicas, según nota de Congar. Pues, desde la época de oro de la Escolástica, la teología fue formulada de manera satisfactoria en términos de ontología, es decir, en lo que tanto Dios como Cristo son en sí mismos; pero los escrituristas se muestran cada vez más de acuerdo en afirmar que la Revelación se ha realizado esencialmente en el marco de una historia, la que es -básicamente- economía o funcionalidad. Económica, en cuanto califica el orden histórico de lo que Dios ha realizado para nuestra salvación o la realización histórica de su designio salvador; y funcional, en cuanto silencia lo «absoluto» o «en sí», midiendo a aquella historia por su relación con nuestra salvación. De ahí que no haya revelación del misterio de Dios y de Cristo más que en la transmisión del testimonio sobre lo que «han hecho y hacen por nosotros», en vistas a nuestra salvación ${ }^{8}$.

Según esto, «Economía» fue la Cristología y la Teología toda, desde los principios de la comunidad cristiana, como se echa de ver en los textos doxo-

5. Congar, Yves M.J., "Cristo en la economía salvífica y en nuestros tratados dogmáticos». Revista Internacional de teología Concilium, año I, nn. 11-14, p. 6, Madrid 1966.

6. ConGAR, Yves M.J., Ibidem, idem.

7. VARIOS, Sacramentum mundi: Enciclopedia teológica, vol. IV, cols. 34-70. Pueden verse también: "Chistologie et theologie» por Wolfhart PANNENBERG, en «Les quatre fleures: Cahiers de recherche et de reflexion religieuses, Le Christ visage de Dieu, n. 4, pp. 85-99. Igualmente "Aproximación a la dogmática cristológica», en Selecciones de teología, vol. 11, n. 42, pp. 168199, abril-junio 1972.

8. Congar, Yves M.J., Ibidem, pp. 6 y 7. 
lógicos, con que la Iglesia confesaba su fe en la alabanza, volcando luego esa alabanza en el hecho del culto, que expresaba su vida y su oración ${ }^{9}$. Textos doxológicos, en los que no se contiene un enunciado teológico o de revelación sobre la «naturaleza» de Dios o de Cristo, más que en el marco de la «economía». Más aún: Cuando san Juan nos dice del Logos, habla del Verbo de Dios que se ha hecho carne, y por el que fueron hechas todas las cosas; de la Palabra creadora y reveladora de Dios y de su existencia por nosotros, más que de su naturaleza divina.

Pero era natural y necesario que la fe dada a los santos, de que una vez para siempre (Jud 3) - acota al respecto Congar - fuera formulada más explícitamente. Lo que podía y debía hacerse por dos caminos, ambos exigidos por la existencia misma y por la misión de la Iglesia. Por el camino de la reflexión de las inteligencias más exigentes, en contacto con la cultura humana y en la búsqueda de una unidad en el ámbito de la verdad; y por el camino de una defensa e ilustración de la herencia, transmitida desde los Apóstoles, contra interpretaciones y formulaciones que ponían en peligro su sentido auténtico y la esencia misma de su contenido ${ }^{10}$. Cosa que se hizo interpretando en términos ontológicos los enunciados de la Escritura. Y es que no se pueden orillar las cuestiones en la donación de una respuesta de fe a la Palabra de Dios, y en el compromiso que en sí entraña esa respuesta, sin decir lo que son las realidades, acerca de las cuales las Palabra de Dios hace determinadas afirmaciones.

Así obró la primera generación de discípulos de Cristo en su primer trabajo de interpretación y de profundización de los hechos y los dichos de la historia evangélica primitiva, siendo incorporado aquel trabajo en los escritos más tardíos del Nuevo Testamento, particularmente en los de san Juan. Y así también lo hicieron la segunda y tercera generación - sigue anotando Congar - al pensar el misterio cristológico y trinitario, precisamente a partir de las fórmulas «económicas» de la Escritura -en plan ontológico insuficientemente elaboradas - hasta llegar a una expresión, no satisfactoria, de las afirmaciones ontológicas, contenidas en aquellas formulaciones ${ }^{11}$.

Por lo tanto, cuando la «economía» saltó a hacerse teología o Cristología, halló dificultades ontológicas, máxime por tener que definirse con conceptos platónicos, estoicos y filonianos, precisamente para combatir el platonismo, el estoicismo y el filonismo. Pero se intentó, lográndose salvar - en gran parte- lo que estaba en juego: la verdad de la afirmación esencial de la divinidad de Cristo, la cual no sólo está afirmada en expresiones de la Escritu-

9. Rom 10,9; Fil 2,6-11; Act 2,36.

10. Congar, Yves M.J., Ibidem, p. 18.

11. Congar, Yves M.J., Ibidem, p. 19. 
ra, sino que venía exigida por la verdad plena de la obra que Cristo había realizado en favor nuestro, en beneficio y por causa de nuestra «economía». Aparte de que con ello se ponía en claro que la Revelación del misterio de la Santísima Trinidad era igualmente "económica»; pues las Personas divinas quedaban reveladas como concatenantes e insertas en el plan del hombre rescatado y en la obra toda de Cristo Redentor.

Un poco más tarde, en los siglos IV y V, durante las grandes discusiones trinitarias y cristológicas, los Santos Padres fundamentaron ya correctamente el «en sí» de Dios sobre la economía o «por nosotros», uniéndose -a maravilla- entonces ya «economía-teología-Cristología-ontología», según lo van cantando gloriosamente aquellos apotegmas teológicos agustinianos: «Todo lo redimió quien todo lo creó» ${ }^{12}$; «el Verbo de Dios se hizo carne, asumiendo lo que no era y sin perder lo que era» ${ }^{13}$; «Cristo es carne, Cristo es alma, Cristo es Verbo; pero estas tres cosas no son tres Cristos: Son un solo Cristo. Mira a ti mismo, oh hombre, y de ti mismo forma un escalón para subir a lo que está sobre ti, si no para entenderlo, al menos para creerlo. Que como el cuerpo y el alma son un solo hombre, así el Verbo y el hombre son un solo Cristo" ${ }^{14}$.

$\mathrm{Y}$ es que Dios, es que Cristo ha salido como de su «en sí»-comentando va Congar los textos agustinianos- sin abandonarlo, y ha entrado en nuestro mundo, en nuestra historia, en nuestra «economía», para hacernos partícipes de su vida, de su alegría, de su inmortalidad, de su gloria. Pero esta intención «económica», el compromiso, la manifestación y las operaciones funcionales o salvíficas que suponen, exigen - para ser verdaderas y salvíficas - la plena verdad «en sí» de Cristo y de Dios, en la medida en que nosotros podemos hablar de ella, a partir de la Revelación. En una palabra: Cristo «no hace» lo que hace por nosotros, si no «es» lo que es en sí mismo. Y solamente porque Cristo es Dios, su humanidad es redentora y santificadora. Pues no podrían pensarse correctamente las afirmaciones «económicas» sobre la actividad de Cristo, Redentor y Salvador, si no es llevando la reflexión hasta el nivel del «en sí», siendo este proceso teológico el acontecimiento que puso de manifiesto la insuficiencia de las fórmulas -exclusivamente «funcionales»- en esta materia. Lo que mejor se echó de ver con la aparición del monotelismo en el siglo VI ${ }^{15}$.

12. SAN Agustin, Serm. 237, n. 4 .

13. SAN Agustín, Serm. 291, n. 2.

14. San Agustín, Tract. in Jo. 47, n. 13.

15. Congar, Yves M.J., Situación y tareas de la teología hoy, p. 126. Colección «Verdad e Imagen», 11. Ediciones Sígueme, Salamanca 1970. Traducción del original francés por Sergio Gómez y Agustín Redero. 
Desde entonces y, sobre todo, en el siglo de oro de la Escolástica, el misterio de Cristo, la Cristología, la Historia de la Salvación, el Cristocentrismo fueron más teología sistemástica que Historia de la Salvación, aunque la teología - y quizá por ser cristocéntrica - seguía teniendo su carga de Cristología, en el contexto de la «economía». Punto en el que es de notar cómo el tomismo incide más en una Cristología, dentro del objeto de la teología —Dios en cuanto Dios-, distinguiendo en ella una Cristología especulativa (doctrina sobre la Persona de Cristo) y una Cristología concreta (soteriología); mientras que el agustinismo lo hiciera mirando más al Cristo místico, al Cristo total, como hilo conductor y elemento conglutinante de toda la teología, con su motivo de la Encarnación, y de la relación existente entre ésta y la creación ${ }^{16}$.

Más tarde, aquella teología sistemática, heredera del conceptualismo -no de los grandes escolásticos, sino de una escolástica de manuales - al verse obligada a un enfrentamiento con el subjetivismo religioso de la Reforma, y, posteriormente, con el modernismo, siguió trabajando con una idea de Revelación, convertida en una serie de proposiciones de tipo metafísico, cuya demostración se habría reseryado Dios para la visión -en la consumación del misterio- y no para los caminos de la peregrinación del hombre en esta vida. $Y$ es entonces cuando, con la invocación de un retorno a las fuentes bíblicas, que anima todo el movimiento teológico actual, Karl Barth se sitúa decididamente dentro de un radical cristocentrismo, haciendo de la creación motivo externo de la Alianza o Historia de la Salvación, al tiempo que proclama a la Alianza el motivo interno de la propia creación, y ordena luego toda la teología en base a una reducción cristológica o cristocéntrica. Y es también entonces cuando Abraham Heschel promulga su principio de que «la Biblia no es una teología para el hombre, sino una antropología para Dios» ${ }^{17}$.

Lo cual es cierto y no es verdad - comenta Congar-, porque el dato revelado comporta el «en sí» al mismo tiempo que el «para nosotros» y la Escritura ignora la oposición entre el «para nosotros» y el «en sí», siendo así que algunos de sus enunciados funcionales desembocan necesariamente en lo ontológico, como ya hemos visto. Por todo ello, en la actualidad, la teología se ha centrado en el Misterio de Cristo, se ha hecho panorámica y sustancialmente cristocéntrica; ya que el centro de todo es Cristo y el fin no es otro que Cristo-Dios (cfr. 1 Cor 15,28).

16. VARIos, Sacramentum mundi: Enciclopedia teológica, vol. II: Sobre la cristología y la soteriología, cols. 17-73.

17. Congar, Yves M.J., Situación y tareas de la teología hoy, p. 92, donde cita a la letra el principio de Heschel, diciendo que quien aireó aquel principio de entraña antropológica en la $\mathrm{Bi}$ blia fue A. Lacocque. 
Factores de este cristocentrismo en el misterio de Dios han sido los siguientes, según apunte del propio Congar:

a.- El ya mencionado retorno a las fuentes bíblicas, junto con una vuelta a considerar la fe y la Revelación como un diálogo salvador de Dios con el hombre, que lleva a una apertura total de nuestra parte a Dios, para que Dios reine en nuestras vidas.

b.- La confrontación con el protestantismo, que ha querido ser una crítica radical de ese «cosismo» teológico y cristológico practicado por la Edad Media decadente.

c.- Una afirmación de la relación personal, dramática y paradójica, creada por el acto y el don de Dios entre «mi» salvación que es Cristo, y «mi yo» pecador, al que la fe, realizada por Dios en Cristo, hace propia en mí aquella salvación ${ }^{18}$.

Respecto al último de esos tres factores, cabe subrayar y recordar cómo la Reforma ha visto al cristianismo como esa relación creada continuamente por Dios, como acto y acontecimiento, negando lo estático, lo general, lo ontológico bajo una forma cosista. Angulo, en el que confluyen también las líneas del pensamiento filosófico actual, no pretendiendo formular una interpretación, en conjunto, del mundo en términos de ontología, sino dándola en el abanico de una reflexión sobre la existencia humana, con sus relaciones interpersonales -ontología intersubjetiva-, que es muy distinto de un mero y absoluto subjetivismo. Con lo que la filosofía contemporánea ha contribuido a crear ese clima de relación interpersonal religiosa de la fe, despertada por la revelación, y en la que la teología católica viene desarrollando el auténtico compromiso del hombre con la «economía» del misterio de Cristo ${ }^{19}$.

En consecuencia, la revelación del misterio de Cristo y el propio misterio de Cristo es economía y es historia. Dios se ha dado a conocer en los actos y en las palabras, por los que declara y realiza su alianza y su salvación; pero, a partir de lo que hace por nosotros, se conoce realmente algo de lo que Él es, siendo legítimo y normal que la reflexión creyente elabore estos preciosos elementos de conocimiento ontológico.

Misterio de Cristo y Cristocentrismo - teología auténtica- que nos ha enseñado cómo là fe no consiste en admitir simplemente una serie de proposiciones, al tiempo que nos ha dicho que la revelación no consiste exclusivamente en una lista de tales proposiciones, subsanando así una deficiencia de la teo-

18. Congar, Yves M.J., Cristo en la economía salvífica, p. 15.

19. Congar, Yves M.J., Ibidem, p. 16. Advertimos que este artículo, publicado primeramente en la revista Concilium, luego fue publicado con algunos otros más en Situación y tareas de la teología hoy, pp. 104-135. 
logía tradicional, de la predicación y de la catequesis, cual ha sido la atomización temática de nuestras creencias, sin relación a un centro único, viviente y transcendentalmente cordial: Cristo. Y, si ya el Concilio Vaticano I - hace más de un siglo- abría a la teología una ventana de luz a este respecto, diciéndonos que «la razón, ilustrada por la fe, cuando busca cuidadosa, pía y sobriamente, alcanza por don de Dios alguna inteligencia y muy fructuosa de los misterios, ora por analogía de lo que naturalmente conoce, ora por la conexión de los misterios mismos entre sí y con el fin último del hombre» ${ }^{20}$, aquella ventana de luz hoy se ha hecho faro esplendoroso y mar abierto, en el que navegamos - a velas desplegadas - sabiendo que Dios mismo ha dado a su Revelación la unidad de un designio, que no es otro que la salvación y la felicidad del hombre - con el universo y no separado de él- por la comunión con él en Cristo.

Deficiencia aquella de la teología sistemática, de la predicación y de la catequesis que, al incidir en el «en sí»» de Dios y de la religión, sin insistir al mismo tiempo en la dimensión de «para el hombre» - los dos polos de atracción en Cristo- creó un mundo y un hombre sin Dios, que - hasta hace poco- estuvo en franca rebelión contra ese Dios sin hombre y sin mundo. Ateísmo desafiante, en el que todavía se debaten muchos de nuestros contemporáneos, y al que es preciso salir al paso poniendo de manifiesto el impacto de las cosas de Dios. Sin que eso signifique reemplazar la transcendente representación del «en sí» por un programa o mensaje puramente humanista y antropológico, pues caeríamos en el mismo error separatista que queremos superar, aunque ahora en sentido contrario. Hay que saber unir la antropología con la teología, la antropología para Dios con la teología para el hombre, en el espíritu de una Revelación que es «económica», sin dejar de ser teológica ${ }^{21}$.

Pues la teología - que ha sido y será siempre una reflexión acerca del contenido de la fe y de sus misterios- no debe hoy permanecer ni aparentar extraña a la corriente de la vida, a la cultura de los hombres, al servicio del Pueblo de Dios que avanza por la historia del mundo, ni debe ignorar los problemas que vienen solicitando a los espíritus. Problemas nuevos o formas nuevas de los problemas de siempre, cuya solución parece reclamar de la teología una reflexión más profunda acerca de las condiciones generales de la fe y acerca de la posibilidad de creer. «Estamos llamados - nos dice en otra de sus obras Congar - a estudiar y trabajar la teología de siempre, procurando,más que en otros tiempos y en las condiciones nuevas del mundo, desarrollar los aspectos del misterio de Dios, que son para el hombre. Lo cual no ha de re-

20. Concilio Vaticano I: Const. dogma. Dei Filius, cap. 4. Dezinger n. 1796.

21. Congar, Yves M.J., Cristo en la Economía salvífica, p. 25. 
dundar, de ningún modo, en disolver la teología en una antropología, sino en desarrollar mejor el vínculo que Dios mismo ha puesto entre nosotros y Él, creándonos a su imagen y tomando partido por nosotros y por nuestro mundo, de tal modo que, por la encarnación de su Verbo, se ha unido definitivamente a nosotros» ${ }^{22}$.

\section{Misterio de CRisto e historia de la SAlvación}

Casi al comenzar este trabajo dijimos que la Revelación de Dios en Cristo es abrirse históricamente Dios al mundo y donarse a él en el misterio de Cristo. $\mathrm{Y}$ acaso convenga ahora centrar más la conexión existente entre Revelación y Misterio, para poder incidir - más tarde - sobre el misterio de Cristo en la historia de la Salvación.

Empezaremos, pues, por decir que de dos modos ha llevado a efecto Dios su automanifestación al mundo: Uno de ellos por la creación y su obra, y el otro mediante el Verbo hecho carne. De ahí la doble denominación de revelación natural y revelación sobrenatural. En ambas vertientes el objeto de la revelación es Dios mismo; el motivo es el amor de Dios, y la finalidad es la realización de la caridad divina, bajo formas sensibles y para nuestra salvación. Motivo y finalidad que, siendo términos relativos en nuestro modo de hablar, vienen a decirnos del amor con que Dios ama su propia infinitud y su grandeza, y que, al contemplarla - exuberante de comunicación y de vida- se siente como impulsado y movido a comunicarla más allá de su propio Ser y de su propia vida. Con todo, al decir de la revelación sobrenatural, de la automanifestación de Dios al mundo mediante Cristo, es necesario subrayar que su finalidad radica solamente en la realización - bajo una forma finita $y$ sensible- de lo más íntimo de la vida divina, de la vida del Amor en la Trinidad, tendiendo siempre a la participación de las criaturas en la vida divina del amor ${ }^{23}$.

Y nada diremos sobre esa automanifestación histórica de Dios, que se realiza o por medio de la palabra divina o mediante el obrar de Dios y -a las veces- por medio de los dos modos; relevando tan sólo que el carácter histórico de la revelación divina alcanzó la cumbre de la autodonación en el amor, con Cristo. Cuando el Verbo eterno de Dios entró en la historia de los hom-

22. Congar, Yves M.J., La fe y la teología, p. 16. Editorial herder, Barcelona 1970. Traducción al castellano del original francés: «La foi et la Theologie» por Enrique Molina.

23. Alfaro, J., «La fe como entrega personal del hombre a Dios», artículo publicado en la revista Concilium, año III, vol. I, p. 60ss. Madrid 1967. 
bres, hecho hombre. Cuando la Palabra creadora del Padre, a la que y en la que eternamente Dios manifestó toda la riqueza del Ser y de la vida, transcurrido el tiempo previsto, fue enviada al mundo para la salvación del hombre. Cuando todo el movimiento del plan eterno de Dios, que tendía a la perfección de la comunicación de sí mismo, convergió en la Encarnación del Verbo por y para el hombre. Cuando el Verbo tomó la carne humana, y plantó la tienda de su habitación entre nosotros (In 1,14), para alcanzar nosotros la redención al precio de su sangre (Ef 1,7).

Inserción del Verbo divino en la historia, con lo que toda la Revelación sobrenatural se ha consumado, ya que el Verbo encarnado, Cristo, en su aparición, en sus obras y en sus palabras es la Revelación de Dios, es el misterio de Dios hecho vida y manifestado en el misterio de Cristo. De donde -como puntualiza Bakker - resulta que, desde los comienzos mismos de la comunidad cristiana - de la Iglesia - la presencia absoluta y redentora de Dios en Cristo, haya sido el dato bíblico fundamental, el más original y el más pletórico de la revelación, ya que es su plenitud ${ }^{24}$.

Lo fue y lo será. Por ello Cristo fue siempre el ser de la reflexión constante de la humanidad, ávida de conocer todo lo que signifique ocultamiento o misterio, aunque Cristo y su misterio no nos revelà, a plena luz, el misterio de Dios, porque «Dios habita en una luz inaccesible» (1Tim 6,16), sino en signos que, a la vez que algo nos desvelan, algo todavía van velando, hasta que «con Cristo seamos manifestados en la gloria» (Col 3,3-4). Porque al presente nuestro conocimiento es imperfecto hasta que, al fin, desaparezca esa imperfección, ya que ahora vemos como en un espejo y oscuramente hasta que llegue el momento de verle cara a cara (1Cor 13,9-13). Porque ahora somos hijos de Dios, a pesar de que aún no se ha manifestado lo que hemos de ser, $\mathrm{y}$, cuando se manifieste, seremos semejantes a Él, porque le veremos tal cual es (1Jn $3,2-4)$. Y es que tal es lo propio del misterio: Ser comprendido en algo - no en su plenitud, pues ya no sería misterio- y justamente ser comprendido mediante el signo visible que al misterio oculta y significa.

Así, pues, el eterno «misterio de Dios» se hizo temporalidad divina y divina revelación en el «misterio de Cristo»; y este «misterio de Cristo» se prolongó, en el tiempo, en el «misterio de la Iglesia». Porque la Iglesia es el misterio viviente de Cristo, así como el Cristo histórico es el misterio eterno de Dios, revelado, en el tiempo y al hombre, en la Persona del Hijo. «La Iglesia - transcribimos de De Lubac - es el sacramento de Jesucristo. Lo cual, empleando otros términos, equivale a decir que la Iglesia se encuentra en cierta

24. BAKKeR, L., «Lugar del hombre en la divina Revelación», publicación en la revista Concilium, Ibidem, pp. 37-40. 
relación de identidad mística con Jesucristo. Y aquí volvemos a encontrar las metáforas paulinay las demás imágenes de la Biblia, que la tradición cristiana no ha cesado de explotar» ${ }^{25}$.

Metáforas paulinas alusivas al misterio de Dios - que es Cristo- en las que el Apóstol distingue tres fases: El misterio de Dios en sí mismo (1Cor 2,7-9); Ef 1,1.10 y 3,9-10); el misterio de Dios revelado (1Cor 2,10; Ef 3,5-10); y el misterio de Dios proclamado (Tit 1,1-3; 1Tim 3,16). Tres fases, con las que va coincidiendo Pou Rius cuando nos dice: «No es ninguna paradoja decir que la gran realidad desconocida es el «misterio». Para el lenguaje humano el misterio es la incógnita; sin embargo, el «misterio» de que nos habla la revelación es Cristo, en nosotros manifestado, proclamado y vivido. Este misterio, en el que toda la humanidad está incorporada, por ser la realidad suprema de la Sabiduría de Dios, es la gran realidad desconocida»" ${ }^{26}$.

Tres fases o tres tiempos - nos dirá en otro lugar De Lubac- en los que va entrañada la historia toda de nuestra salvación o la economía de Dios, que es el despliegue del divino obrar en favor del hombre. De ahí las tres series de operaciones que son de naturaleza diversa, y cada una de las cuales es atribuida por nuestro Credo a cada una de las tres Personas, aunque -desde siempre se ha sabido también - que ninguna de las Tres hace nada separada de las otras dos. Así, pues, al Padre le corresponden las obras de la creación; al Hijo las obras de la redención; al Espíritu Santo las obras de la santificación. Obras en conjunto y al unísono de acción en las tres Divinas Personas, que hacen de nuestra salvación y de su historia una «economía trinitaria»... Hasta tal punto que la creación prefigura el misterio redentor, y que el libro de los Hechos de los Apóstoles haya podido ser designado como «el libro de la Iglesia» y como «el Evangelio del Espíritu Santo», llevando a cabo en los redimidos los efectos de la obra redentora, realizada en su tiempo por Jesucristo ${ }^{27}$.

El fin de la Revelación -apuntábamos más arriba- es nuestra salvación, y no hay revelación particular alguna que no haga referencia a esta meta última, querida por Dios, por eso, el «misterio de Dios» es el misterio de nuestra salvación, revelándose en el «misterio de Cristo» y prolongándose en el «misterio de la Iglesia», justamente por ser su Encarnación el punto de arran-

25. De Lubac, H., Meditación sobre la Iglesia, cap. VI, p. 181. Colección «Veritas et Justitia», 4. ${ }^{a}$ ed., Desclée de Brouwer 1964. Versión española de la 2. ${ }^{a}$ edición francesa: «Meditation sur l'Église», por Luis Zorita Jáuregui.

26. Poy Rius, R., Nuestro misterio. Dimensiones bíblicas del culto cristiano. Editorial Estela, S.A., $1 .^{a}$ ed., p. 16, Barcelona 1962.

27. De Lubac, H., La fe cristiana, cap. III, pp. 119-132. Ediciones Fax, Madrid 1970. Traducción española de la $2 .^{\text {a }}$ edición francesa «La foi chretienne», revisada y aumentada por Constantino Ruiz-Garrido. 
que del ser y del misterio de la Iglesia, cuando el invisible se hizo visible a nuestros ojos, dejándonos ver - hecho hombre- la bondad de Dios nuestro Salvador y su amor a los hombres (Tit 3,4). Y es en esta Encarnación del Verbo, en esta venida de Dios en nuestra carne, como mejor conocemos hasta qué punto y de qué modo el Absoluto es Amor y generosidad. No solamente en visión de conjunto, como gloria y victoria, sino - ante todo- como humildad y abajamiento, en aquel sentido de positividad y humillación extrema que entraña la elección y la aceptación por Cristo de su condición humana, en una situación que se vio determinada por la incredulidad que entre los hombres halló, como discurre profundamente Schoonenberg ${ }^{28}$.

De donde la Navidad es el principio de ese maravilloso y tremendo movimiento, por el cual el Hijo de Dios - resplandor de su gloria e imagen de su substancia - se anonada adoptando la condición de esclavo. Anonadamiento que es abajarse el Absoluto en lo relativo, la Eternidad al tiempo, el Creador en la criatura, el Ser eterno en el mundo de los seres temporales, el Santo en la carne de pecado, para que lo relativo fuera llevado al Absoluto, a la Eternidad el tiempo, el hombre el Creador. Y el cielo, esto es, la salvación -concluye en otra parte Congar - se realiza cuando la relación de los seres, que forman el todo del universo con el Ser, sea perfecta, y Dios sea todo en todos (1Cor 15,28), según llama san Pablo a tal estado de cosas ${ }^{29}$.

En Cristo encarnado y crucificado -nos dice por su parte Schmaus- vemos el misterio divino, oculto y escondido desde la eternidad, y que ahora se anuncia y revela en la Iglesia por medio de Cristo, claro está que veladamente ${ }^{30}$. De ahí que Cristo -epifanía o manifestación de Dios- es el único misterio de Dios, comenzándosenos a revelar en y por su Encarnación misteriosa. Que Cristo allí elevó -y elevándola la divinizó- nuestra naturaleza, haciéndola signo eficaz de la comunicación de Dios al hombre. Que Jesucristo, haciéndose hombre y asumiendo por su encarnación la naturaleza humana, se ha hecho manifestación de la bondad divina y del amor sin límites de Dios, se ha hecho revelación del amor inmenso que Dios tiene a los hombres. Y, de este modo, se nos hizo «camino» que conduce a Dios. Vino a unir a Dios con el hombre y al hombre con Dios, para hacer realidad la comunidad de amor en-

28. Schoonenberg, P., «Kenosis-Anonadamiento», artículo publicado en la revista Concilium año II, vol. I, n. 11, pp. 60-71. Madrid 1966.

29. CongaR, Yves M.J., Jesucristo, nuestro mediador, nuestro Señor, parte I, pp. 33-34. $2^{\text {a }}$ ed., Editorial Estela, S.A., Barcelona 1967. Traducción al castellano por León M. Sansegundo, monje de Montserrat, del original francés: «Jesus-Christ», según les Editions du Cerf de paris.

30. Schmaus, M., Teología dogmática, vol. VI: Los sacramentos, p. 22. Ed. 2. ${ }^{\mathrm{a}}$, Rialp S.A., Madrid 1963. Traducción del alemán: «Katholische Dogmatik», por Julio García Ortega y Raimundo Drudis Baldrich. 
tre Dios y el hombre. Lo que hizo efectividad esplendorosa con su vida, muerte y resurrección, que viene a ser la expresión tangible, el signo que aparece ante los pueblos y los hombres, y que les descubre el amor redentor. Jesucristo es, pues, la realización y manifestación del amor salvífico de Dios con los hombres, el signo eficaz de la unión íntima del hombre con Dios.

El hombre - como término y destinatario gozoso del amor de Diosqueda así ligado a Cristo, de manera que resulta imposible su separación. Cristo se encarna por el hombre y para el hombre, teniendo aquel misterio una finalidad concreta: la redención del hombre, la salvación del hombre ${ }^{31}$. De tal modo, que toda la historia del hombre se centra en Cristo, y él recapitula en sí toda la historia; pues, antes de la Encarnación, la historia se orienta ya hacia Cristo y, después de la Encarnación, la historia desemboca en Cristo, siendo Cristo la plena realización de la historia del Nuevo Testamento. Ya que en el Antiguo Testamento estaba - hasta cierto punto- como oculta la acción divina, redentora siempre y siempre salvadora, porque él era como un velo que ocultaba a los hombres ese plan divino y que impedía la clara visión de Dios para con la humanidad; pero, en el Nuevo Testamento, al hacerse el Verbo carne en el Ser de Cristo, y al revelarse el eterno misterio de Dios en el misterio de Cristo, aquel velo se rasgó, apareciéndose - como realidad visible y palpable - aquel plan misterioso y salvífico de Dios.

A este efecto, bueno será recordar tan sólo tres textos agustinianos que cantando van la prefiguración del Nuevo en el Antiguo Testamento. «Ves - dice san Agustín - el Antiguo Testamento revelado en el Nuevo, y el Nuevo velado en el Antiguo» ${ }^{32}$. «Cuanto se halla escrito en el Antiguo Testamento -apunta en otro lugar- no es más que un pregón continuado de Cristo» ${ }^{33}$. Y en su Ciudad de Dios subraya: «Los hechos realizados y consignados en el Antiguo Testamento, no lo han sido sin alguna prefiguración de lo porvenir, y que deben referirse a Cristo y a su Iglesia, que es la Ciudad de Dios» ${ }^{34}$.

Según ello, tanto en la perspectiva de la Escritura como en el decir de los Padres y en el hacer de la Liturgia, el «misterio de Cristo» revelado, que comienza con la Navidad, comprende ya todos los misterios de la salvación y de los cuales es consumación la Pascua. El mismo san Pablo nos señala cómo él ve la venida en la carne del Verbo de Dios ya en la línea de la Pascua; pues a la Pascua está mirando el sacrificio (Fil 2,7-11), en la Pascua está centrado el gozo de la resurrección (Rom 1,3-4), de la Pascua surge la gloria indeficiente y las galas de la redención (Gál 2,4-5), y hasta la misma filiación divina de Cris-

\footnotetext{
31. SAn Agustín, Serm. 127, n. 9.

32. SAN Agustín, Enar. in Ps. 105, n. 36.

33. SAN AGUSTí, Exp. in Epist. Jo ad partos, trat. 2, n. 2.

34. San Agustín, De Civ. Dei, lib. XVI, cap. 2, n. 3.
} 
to divinamente se manifiesta en la Pascua, seguida de su entronización a la derecha del Padre (Rom 1,4; Hebr 1,5 y 5,5). Filiación divina de Cristo que también mira a nuestra filiación de gracia, a nuestra redención y a nuestra divinización por la Pascua del Señor; ya que todo eso únicamente puede ser verdad en nosotros, si y porque aquel, que por nosotros ha nacido, ha muerto, ha resucitado y ha subido victorioso al cielo, no es otro que el Hijo de Dios.

Perspectiva transcendente ésta de la Resurrección y de la Pascua, que -en palabras de Vögtle - es el hecho histórico, auténtico, definitivo y fundamental de la fe cristiana, y que es clave determinante para comprender en toda su dimensión el misterio de Cristo y de la Historia de la Salvación ${ }^{35}$. Pues la Historia de la Salvación es una realidad que crece en la historia, siendo su contenido quintaesencia que transciende el enfoque fenomenológico de la existencia humana, y como un camino intermedio entre dos puntos de vista -en controversia cristiana-, como son el de Bultmann y el de Cullmann, tal como nos lo hace ver Ratzinger. Bultmann con su kerigma, como acontecimiento escatológico y atemporal, que conduce al hombre desde una existencia alienada a la existencia auténtica; y Cullmann, para quien lo decisivo es la serie de acontecimientos operados por Dios, y en la que el yo se encuentra inserto por la fe. De donde surgieron los extremos de estas dos antítesis: metafísicahistoria de la salvación, historia de la salvación-escatología. Callejón -aparentemente sin salida - al que el propio Ratzinger abre camino, basándose en el «me voy y vuelvo a vosotros» (Jn 14,28) del mismo Cristo, y diciendo a la historia de la salvación como aquella acción de Dios que -en su objetividad esencial- no es algo opaco y sin ningún alcance salvífico, sino la auténtica fórmula de la existencia humana, que posee su «en sí» precisamente «fuera de sí» y que sólo se realiza en el «ex-sístere» de sí mismo. De donde —así va concluyendo Ratzinger - el Dios «es» hombre es la fórmula que en toda su profundidad encierra la realidad pascual, haciéndose, de un hecho transitorio, el eje de toda la historia salvífica en que estamos insertos ${ }^{36}$.

Pero, una vez vuelto Cristo al Padre, el «misterio de Cristo» sigue viviente en el «misterio de la Iglesia», según reseñábamos más arriba ${ }^{37}$; pues la Iglesia y Cristo, el Cuerpo y la Cabeza son como una persona única, nos dirá san Agustín ${ }^{38}$. Y a la Iglesia que vive en Cristo, por Cristo y con Cristo, Cristo

35. Vogtle, A., «Revelación e historia en el Nuevo Testamento», artículo publicado en la revista Concilium, año III, vol. I, n. 21, pp. 41-55, Madrid 1967.

36. RATZINGER, J., Teología e historia: Notas sobre el dinamismo de la fe. Colección «Verdad e Imagen», Ediciones Sígueme, pp. 46-69. Salamanca 1972. Traducción al castellano por A. Caballos e I. Camacho.

37. Cfr. supra, con referencia a nota 25 .

38. San Agustin, De Doctrina Christiana, lib. III, cap. 31, n. 44. 
confió su revelación - «su misterio proclamado y vivido» ahora- para que ella la siga comunicando a los hombres todos hasta la consumación de los siglos, siendo la Iglesia ahora el órgano de aquella divina revelación. Y a fe que la Iglesia se halla tanto más capacitada para cumplir esa misión salvífica, cuanto que la unen con Cristo - por el Espíritu Santo y por la gracia- los lazos que al Cuerpo unen con la Cabeza, sirviendo de mano a Cristo para ejecutar los signos de la revelación, determinados por el Padre, y sirviendo de boca ella a Cristo para anunciar a los hombres el mensaje de la salvación. De este modo, la revelación - consumada en un momento dado (1Tim 6,14; Tit 2,13 ) - sigue subsistiendo perennemente, y todos podemos oírla y verla; y tanto los sacramentos - palabras visibles de la salvación - como la doctrina eclesiảstica - signos audibles de esa misma salvación - son los instrumentos por los que Cristo actualiza en todos los tiempos su revelación temporal, hasta que ésta quede perfectamente consumada al final de los tiempos, quedando esclarecidos entonces tanto el término como el sentido de todas las etapas de la Historia de la Salvación.

Que una de las adquisiciones más decisivas del último siglo - nos rubricará Congar - ha sido el redescubrimiento de la escatología, no ya como último capítulo de una teología estática, sino como realidad que determina el sentido mismo de lo que ocurre en la historia. Pero toda esta historia - añade - tiene un centro en el hecho de Jesucristo, en quien lo que nosotros esperamos ha venido ya a nosotros, como en su principio o en su germen ${ }^{39}$. Y de ahí el sentido y el valor de la Iglesia y su misterio, como peregrina por el tiempo. Que el pensamiento eclesiológico ortodoxo, desde los albores de su existencia, consideró su entraña misma como realidad invisible y divina, como unidad de fe y de amor. Así, los Padres griegos se mantuvieron en las profundiades de una cristología, vivificada por el Espíritu, en la cuerda pneumatical, a la que tanto se ha aferrado la teología dialéctica moderna, cuyo exponente máximo quizá sea Karl Barth. Mas, no conviene supervalorar lo interno y carismático - nos avisa Schmaus- a expensas de lo jurídico e institucional. Que Cristo no es divisible, y su Iglesia es, sí, un organismo viviente regido por el Espíritu; pero es también una institución y un acontecimiento histórico. La Iglesia es un ideal de salud y una historia de la salvación, una esperanza y una realidad, un aleteo del Espíritu y una organización al mismo tiempo jerárquica y visible ${ }^{40}$.

Por lo que, aunque hoy se dé preferencia al misterio, no se debe paliar o silenciarse o negar lo visible y orgánico, para no correr a abismos de subjetivi-

39. Congar, Yves M.J., Cristo en la economía salvifica, p. 6.

40. Schmaus, M., Teología dogmática, vol. IV, p. 657ss. 
dad ni a ensueños de quimera, como nos advierte De Lubac ${ }^{41}$. Premisas inequívocas, con las que nos centramos en el «misterio de la Iglesia», porque -en realidad- la Iglesia, como Pueblo de Dios, es misterio «en su ser» y también «en su caminar» histórico, siendo, como don de Dios que es y prolongación viviente del «misterio» salvador de Cristo, la única esperanza del mundo y la única poseedora de la verdad revelada en su plenitud; y, por ello, base espléndida de un ecumenismo realista y constructivo en el revivir de aquella eclesiología comunitaria, enmarcada en el misterio de los siglos: Todos los cristianos unidos entre sí y en Cristo. Comunidad de cuantos creen en la divinidad de Cristo, siguen sus pisadas, observan sus preceptos, viven su vida y se aman mutuamente en el perdón.

Pues los elementos de este vivir comunitario y social - con perspectivas de sobrenaturalidad - constituyen el rostro de una Iglesia en lucha perenne. Y el horizonte abierto y claro de esta Iglesia nos ofrece la posibilidad de divisar una asombrosa policromía de liturgias, tradiciones y creencias, informadas por ese despliegue imponente de la caridad, con acicates de unidad. Que a todos los pueblos de la tierra invita esta Madre a vivir en unidad de fe: lo mismo al sintoísta que al hebreo, igual al musulmán que al hindú, lo mismo al budista que al sincretista. Todos tienen -en potencia - un lugar reservado en la casa de Dios, porque la sangre de Cristo tiene virtud redentora universal.

Misterio eclesial que se inserta en el propio «misterio de Cristo» y, en consecuencia, la Iglesia - como prolongación del misterio del Verbo encarnado- se entronca y enraíza con el decreto divino - libre, amoroso y redentor - de nuestro rescate, dentro de la Historia de la Salvación. Tiene la Iglesia, es cierto, sus estructuras externas, su organización jerárquica y visible; pero, en su esencia, es una realidad misteriosa, invisible y sobrenatural. Nace jubilosa, radiante y bella del costado de Cristo ${ }^{42}$, arropada en las sedas de un misterio de entrega amorosa, siendo los hombres los beneficiarios de la vida divina que la sangre y la muerte de Cristo nos legara. De donde la fe y los sacramentos son como la savia vital de esta Esposa que nos perpetúa a Cristo, y viene a ser como la presencia misma de Cristo entre nosotros (Col 1,27-28), al tiempo que sus funciones sacramentales son como las venas, por las que corre la vida que forma los miembros del Cuerpo místico de Cristo, cuya Cabeza es el mismo Cristo.

Así, pues, en y por la Iglesia, al entrar el hombre en el dominio divino y en la unidad con Cristo, consigue su salvación con la participación en la vida, muerte y resurrección de Cristo, y, mediante ella, en la gloria de Dios. De este

41. De Lubac, H., Meditación sobre la Iglesia, p. 19.

42. SAN Agustin, Trat in Jo. 15, n. 8. 
modo camina de la muerte a la vida, de la desgracia a la gracia, de la lejanía a la intimidad de Dios, del abandono a la seguridad, de la indignidad al honor y de la deshonra a la gloria ${ }^{43}$. De tal manera que el misterio de Cristo es progresivamente mejor comprendido en la fe predicada por la Iglesia y en los sacramentos de la fe por la Iglesia administrados. Y es que en la Iglesia -en su palabra y sacramentos- está Cristo presente hasta el fin de los tiempos como Santificador. Santificador de su Iglesia por esa fuerza divino-vital que Él posee como Dios-hombre, y que al hombre hace más inteligible su «propio misterio» en este otro del «misterio Iglesia», en el que Él es la Cabeza y nosotros — con la Iglesia y en la Iglesia - su Cuerpo místico. «Que el mismo Cristo -dice a este respecto Schmaus- es un admirable sacramento que se desarrolla, se prosigue y se cumple en el sacramento de la Iglesia» ${ }^{44}$, haciendo que la plenitud de la vida divina salte del ámbito intradivino, avance hasta la naturaleza humana de Cristo y - penetrándola - la rebasa hasta llegar, a través de los signos sacramentales, al «yo humano» que cree en Cristo.

Misterio este de Cristo que obra la pacificación de todas las cosas mediante la sangre de la Cruz (Col 1,20), y que vive y opera en el misterio de la Iglesia, perpetuando la obra redentora y sacerdotal de Cristo eminentemente por la sagrada Liturgia, que «constituye el culto público que nuestro Redentor, Cabeza de la Iglesia, tributa al Padre celestial, y el que la sociedad de los fieles tributa a su Fundador y por Él al eterno Padre; y, para decirlo todo en una palabra, constituye el culto público íntegro del Cuerpo místico de Jesucristo, es decir, de la Cabeza y de sus miembros» ${ }^{45}$. Culto público en el que la Iglesia se muestra eficaz en todos los órdenes de la salvación profunda, realizada ya por Cristo, en virtud de la misión por Cristo a ella encomendada, y de los poderes que el mismo Cristo le otorgó. Y eficacia salvífica de la Iglesia que produce en el creyente una vida nueva (Rom 6,4), la gracia y la santidad (2Cor 12,9-11; Gal 1,3-5), y la filiación divina (Rom 8,14-17; 1Jn 3,1-2), justamente por los sacramentos, expresión de lo que la Iglesia es -como figura y como misterio- en la economía correspondiente a este período de la Historia de la Salvación, que es el tiempo de la Iglesia, en el que la salvación está ya realizada, pero aún oculta (Col. 3,4; $1 \mathrm{Jn} 3,2)$. Y, de entre los sacramentos, fundamentalmente por el del bautismo y la eucaristía, que sintetizan la intervención salvífica básica de Dios en la vida de los hombres - a través de la Iglesia - al crear un nuevo hombre por el Espíritu y el agua (Jn 3,5), y al alimentar en

43. San Agustin, Serm. 194, n. 3.

44. Schmaus, M., Teología dogmática, vo. III, p. 309:

45. Encíclica Mediator Dei, del 20 de noviembre 1947. Denzinger, n. 2298. Cfr. Vaticano II: Constitución sobre la Sagrada Liturgia, Sacrosanctum Concilium, nn. 5 y 7. 
aquel hombre nuevo la nueva vida con el cuerpo y la sangre del Cordero sacrificado, que quita el pecado del mundo, significando y realizando la comunión de vida entre Dios y el hombre (Jn 13,18-30; Lc 22,11-20; 1Cor 11,23-26).

Sacramentos que, al tiempo que son memorial o recuerdo de las intervenciones salvíficas de Dios en el pasado de la historia, y realidades vivificantes de la salvación cristiana en y por la Iglesia en el presente, son también profecía de la intervención futura, de la consumación de la salvación definitiva y gloriosa que comportará la Parusía, aquella manifestación de Cristo en la gloria final del fin del mundo. Parusía, con la que se inaugurará un nuevo estadio en el mundo de la eternidad y de los hombres. Cuando, después de haber pasado la humanidad y el mundo por la muerte y la resurrección (Is 65,17 y 66,22; Mt 24 y $25 ; 2 \mathrm{Pe} \mathrm{3,1-10),} \mathrm{la} \mathrm{humanidad} \mathrm{y} \mathrm{el} \mathrm{mundo} \mathrm{-en} \mathrm{virtud} \mathrm{de} \mathrm{la} \mathrm{obra} \mathrm{salvado-}$ ra de Dios, de su Cristo y de su Iglesia, gloriosamente manifestada - entre en aquel estadio definitivo, que será la consumación de la obra creadora y la fruición gozosa e inacabada de los hombres en un cielo nuevo y una tierra nueva (Apoc 21,1-5 y 22,1-6).

$\mathrm{Y}$ entonces, cuando Dios sea todo en todos (1Cor 15,28), cuando a Dios veamos cara a cara como él es $(1$ Cor 13,12$)$ «en aquella ciudad soberana -que cantando va san Agustín- en la que la victoria es la verdad, en la que la dignidad es la santidad, en la que la paz es la felicidad, y en la que la vida es la eternidad» ${ }^{46}$; en aquella ciudad gloriosa «en la que descansaremos y veremos, veremos y amaremos, amaremos y alabaremos, esencia del fin sin fin» ${ }^{47}$; cuando el misterio de Dios, el misterio de Cristo y el misterio de la Iglesia sean verdad y no signo, sean luz y no velo, sean realidad y no sacramento, entonces la historia de la salvación se habrá consumado a plenitud - tal como san $\mathrm{Pa}$ blo nos la había cantado- con todas las galas del amor divino, siempre ávido de nuestra salud eterna (Ef 1,3-23).

\section{HISTORIA DE LA SALVACION Y CRISTOCENTRISMO}

Es un hecho incontestable que muchos hombres del siglo XX - hasta hace poco creyentes y cristianos- se han enfriado, apartado o rechazado el cristianismo. Unos, porque se han dejado ganar la intimidad por el materialismo; otros, porque se dejaron robar la fe por una mentalidad completamente empírica; otros, porque el hedonismo les cegó las fuentes de la transcendencia; y otros - finalmente- porque no supieron o no quisieron saber compaginar las

46. San Agustín, De Civ. Dei, lib. II, cap. 29, n. 2. 
exigencias de la fe con la transitoriedad de la fenomenología. Y, si no en todos, en gran parte de esos desertores cristianos creemos tuvo preponderancia el haber pensado que el cristianismo no es más que un conjunto de verdades o un sistema de dogmas - más o menos absurdos e ininteligibles - ante los que había que inclinarse y aceptar porque a Dios así se le antojaba o porque la Iglesia así lo ordenaba. $O$ lo que todavía es peor, porque creyeron a ese cristianismo como un cúmulo de preceptos - bastante incómodos- que había que observar, so pena de caer en desgracia de un Dios intransigente o dictador. ¡Tanto y tan negro poso han dejado en el corazón del hombre las dictaduras e intransigencias de los hombres!

Con todo habremos de afirmar que aquellos escapes no son sino equivocación o amañada falacia o engaño prefabricado en los caminos del cristianismo. Porque el cristianismo es sólo y todo Cristo. Ese Cristo - exigente, sí, y comprometedor - pero hecho benevolencia, caridad y autodonación acariciada; ese Cristo que es más que una filosofía, por elevada que se la suponga, o una ética, por sublime que se la conciba; ese Cristo histórico, entroncado substancialmente con el Cristo de la fe, que, muerto por nosotros, de nosotros exige - como afirma Alfaro- el estar con él o contra él, porque, una vez que se nos ha metido en las entrañas mismas de nuestra vida, ya no cabe ante él ni la indiferencia ni el olvido, sino la entrega total o la cobarde traición ${ }^{48}$. Idea sobre la que había ya incidido Juan XXIII en su discurso inaugural del Concilio Vaticano II ${ }^{49}$. Ese Cristo que es el centro de la Biblia y de la historia, de la salvación y de la vida. Por eso, no nos queda más remedio que centrarnos en Él, si ya le conocemos, para mejor hacer que nuestra vida siga teniendo sentido; y, si de Él nos hemos apartado o le tenemos un tanto arrinconado, volver por nuestros fueros en su redescubrimiento saludable, para no forjarnos un cristianismo equivocado o caprichoso.

Y la Biblia es el mejor libro en que podemos conocerle, porque allí es donde Cristo - Dios y hombre- mejor se nos revela en la palabra de Dios y en los hechos divinos que allí se nos relatan, en vistas a Cristo o en Cristo mismo o en su Iglesia, y siempre realizados por Dios para nuestra salvación. Que «la Biblia - nos rubrica ahora Rubio Morán- es en su esencia la historia de la realización del plan de Dios sobre los hombres» ${ }^{50}$. Es la historia de nuestra

47. San Agustín, De Civ. Dei, lib. XXII, cap. 30, n. 5.

48. Alfaro, J., La fe como entrega personal.., pp. 57-58. 746.

49. JUAN XXIII: «Discurso en la inauguración del Concilio Vaticano II», BAC, pp. 745-

50. Rubio Morán, L., El misterio de Cristo en la historia de la Salvación, p. 26. 3. ${ }^{\mathrm{a}}$ ed. Ediciones Sígueme, Salamanca 1968. 
salvación, dentro y en la intersección de las coordenadas de la historia universal, como diría el P. Leturia ${ }^{51}$.

Plan de Dios sobre los hombres - seguimos espigando en la obra de Rubio Morán- que consiste en salvar a los hombres por y en Cristo. Por ello Dios envía a su propio Hijo a la tierra como prenda de su amor (Jn 3,16), a vivir entre los hombres como uno más de ellos, no perdonándolo sino entregándolo a la muerte $(\operatorname{Rm} 8,32)$, para reconciliar al hombre con Dios, para llamarlo a un encuentro personal con él, a un abrazo de amigos que se realiza en Cristo, para entablar un diálogo de amistad con Él, mediante el Hijo, sú propia Palabra, la única que Él entiende ${ }^{52}$.

Este plan de Dios tiene su consumación con la pasión, la muerte, la resurrección y la ascensión de Cristo; pero no se manifiesta de golpe, ni se realiza plenamente en el principio de los tiempos, sino que va siendo preparado con cariño por Dios, hasta el momento oportuno de su realización completa. Momento fijado previamente por el mismo Dios. Y porque Dios sabía que era difícil de entender por los hombres que Dios en persona haya entrado en la historia de los hombres, por ello comenzó escogiéndose un pueblo concreto en la historia -el pueblo de Israel- con el que Dios camina y al que, poco a poco, va educando - por sí mismo o mediante los hombres escogidos por él al respecto- con intervenciones de salvación o de castigo, de ayuda o de abandono, de fracaso o de victoria, hasta hacerle comprender y convencerse por sí mismo de que sin Dios los caminos de los hombres florecen sólo espinas, y de que lo mejor para el hombre es dejarse en las manos de Dios, «porque verdaderamente en Yavé, nuestro Dios, está la salvación de Israel» ${ }^{53}$. Educación de Israel por parte de Dios que fue un proceso lento y largo; pero, al cabo de los siglos, ya el pueblo estaba preparado para aceptar la salvación de Dios, y justamente en y por el fracaso más escandaloso: la Cruz de Cristo.

La salvación, pues, tiene su historia - acota a este respecto Latourelleconstituida por esa serie de intervenciones de Dios en favor del hombre; en esa serie de maravillas que preceden a la maravilla, al prodigio de los siglos, que es el envío de su Hijo al mando; en esa serie de escándalos que van acostumbrando al hombre al modo de actuar de Dios, a la «necedad de su sabiduría» (1Cor 1,17-19), a la aceptación de ser salvado por otro y de otro modo que el humano, a lo divino y por el fracaso de la muerte y la derrota de la Cruz. Punto en el que, con la subsiguiente resurrección de Cristo, el plan de Dios quedó plena-

51. Leturia, P. de, Las coordenadas de la historia universal en la historiología de san Agustín. Burgos 1955.

52. RuBIo Morán, L., op. cit., p. 27.

53. Vaticano II: Constitución dogmática Dei Verbum, sobre la divina Revelación, n. 3. 
mente realizado, por más que permaneciera abierto para su aplicación a los hombres de todos los tiempos y lugares, siendo éste el tiempo de la Iglesia en el mundo, el de nuestra espera, el de nuestro adviento, en el que ahora vivimos, puesta la mirada en el cielo, de donde esperamos el retorno de nuestro Savador $(1$ Tes 1,10$)$ para completar su obra en nosotros ${ }^{54}$.

Todo este desarrollo del plan salvífico de Dios, a través de la historia, es el que nos describe la Escritura diciéndonos de la historia de la salvación, con todo ese cúmulo de intervenciones de Dios a favor de los hombres, al tiempo que nos expone las actitudes del hombre frente aquellas intervenciones de Dios. Así, pues, la Biblia nos describe el plan de Dios - según lo va pergeñando Rubio Morán - en tres etapas:

a.- En su preparación y en su desarrollo, anterior a Cristo.

b.- En su realización por Cristo.

c.- En su aplicación y expansión por la Iglesia ${ }^{55}$.

Tres etapas, sobre las que san Agustín incide con frecuencia en sus sermones. «Durante un a modo de trienio visitó el Señor - nos dice- al género humano, o digamos, en tres coyunturas: Antes de la ley, la primera; la segunda, en la ley; la tercera es ahora, el tiempo de gracia» ${ }^{56}$. Y al hablarnos de la higuera infructuosa, así comentan: «La higuera es el género humano. Los tres años son tres períodos: Uno, anterior a la ley; otro, durante la ley, y bajo la ley de la gracia el tercero" ${ }^{57}$. Tres etapas sobre las que diremos muy brevemente en nuestro recorrido por los caminos de la historia de la salvación, aunque más nos detengamos en Pentateuco - Tetrateuco o Hexateuco, según otros-, por echarse allí los cimientos de aquella historia salvífica, tema que constituye como la espina dorsal de toda la Biblia. Salvación que implica dos aspectos: Uno negativo, que equivale a liberación de una realidad dolorosa - presente o futura-, y otro positivo, en cuanto la salvación tiende a instalar al hombre en un estado nuevo, que suele estar en el extremo opuesto de la miserable condición anterior. De tal modo que al sufrimiento, al dolor, a la esclavitud, a la derrota y a la muerte sucede el bienestar, la alegría, la libertad, la victoria y la vida.

En el punto de arranque de la idea de la salvación está, pues, la constatación y la experiencia de una existencia humana, marcada por el signo de la miseria física y moral. Y ningún libro de la Biblia nos reseña con más realismo,

54. LAtourelle, R., Teología de la Revelación, pp. 535-538. Ediciones Sígueme, Salamanca 1967. Traducción de la 2. ${ }^{a}$ ed. francesa por José Luis Domínguez.

55. RUBIO MORÁN, L., op. cit., p. 29.

56. SAn Agustín, Serm. 72, n. 3.

57. San Agustin, Serm. 110, Maurinos 13, n. 1. 
plasticidad y belleza este punto de arranque que el Génesis en sus primeros capítulos, con aquella serie de tensiones, rupturas y desequilibrios que hacen penosa la vida del hombre. Ruptura de sus relaciones con Dios, manifestada en su expulsión del paraíso, símbolo de la intimidad gozosa y de la amistad con Dios; ruptura de sus relaciones con los demás hombres, manifestada en la hostilidad entre Caín y Abel, y en la dispersión de los pueblos a raíz del episodio de la torre de Babel; ruptura de sus relaciones con la misma creación, manifestada en el duro forcejeo entre el hombre y la tierra, a la que tiene que arrancar sus frutos el hombre con sudor y con trabajo; y ruptura, en fin, de las relaciones consigo mismo, manifestada en esa tensión y lucha interior entre la carne y el espíritu ${ }^{58}$.

Tras esta dura constatación de tensiones y desequilibrios en el hombre - discurre ahora Lamadrid- el Génesis busca el origen de esa realidad dramática, hallándolo no en Dios, que creó todas las cosas buenas (Gén 1,31), sino en una defección original de la raza, de la que fueron responsables directos los primeros ascendientes de la humanidad, pero cuyas consecuencias alcanzaron a todos los hombres ${ }^{59}$. Con todo y paralela a aquella fuerza desintegradora, el Génesis nos describe la actividad salvífica de Dios que trabaja por recomponer las relaciones rotas, restablecer la unidad y el equilibrio perdidos, y recobrar la armonía primigenia. Y así -continúa diciéndonos el mismó autor - junto al castigo de los primeros padres, va caminando ya aquella actividad salvífica de Dios en la promesa del futuro Salvador (Gén 3,15 ); junto al castigo del fratricida Caín va la providencia salvífica que por él vela, en su errabundeo por la tierra inculta (Gén 4,15); junto al castigo del diluvio por haberse mezclado los hijos de Dios con las hijas de los hombres, camina la actividad salvífica del Señor, reservándose la familia de Noé como germen de la nueva humanidad (Gén 6,8); y junto al desenlace trágico de la torre de Babel y la dispersión de la humanidad va aquella actividad salvífica eligiéndose a Abraham como fruto de bendición, en el que recobrarán la unidad perdida los pueblos todos de la tierra (Gén 12,3).

Plan de salvación que, con los patriarcas, empieza a tomar forma completa remarcándose - siempre y en todo - como actividad y elección gratuita de Dios, como lo sugiere el constatar que el poder y la bendición no están a favor del primogénito - como pudiera sugerirlo la ley natural- sino a favor de aquel a quien Dios quiere y elige. Y así vemos cómo - anota en otra parte el autor en referencia - los designios salvíficos se transmiten a través de Isaac y

58. Gén 3,$23 ; 4,8$ y $11,4-10 ; 4,5-16$ y $5,5-8$.

59. Lamadrid, A.G.- Arnaldich, L., Manual Bíblico, Antiguo Testamento, vol. I, pp. 62-63. Editorial Casa de la Biblia, Madrid 1966. 
no de Ismael, de Jacob y no de Esaú, de Judá y no de los tres hermanos mayores, acentuándose la libertad y la gratuidad del plan salvífico de Dios ${ }^{60}$.

De otro lado, si se puede afirmar que toda la Historia de la Salvación está fuertemente articulada en torno a un arco de tensión, que tiene en su punto de arranque la promesa y en su término de llegada el cumplimiento de la misma - factor éste que da a toda la Biblia unidad, cohesión y dinamismo- esto se ve especialmente en el Pentateuco. Que en él se dan unas promesas de carácter general y espiritual, orientadoras de toda la historia de la salvación hacia metas lejanas e imprecisas, tales como las del Protoevangelio (Gén 3,15 ) y la bendición de todos los pueblos en Abraham (Gén 12,3); pero mientras llega el tiempo de su cumplimiento cabal, la historia de la salvación se vio alimentada por promesas parciales, a corto plazo y de índole más material. Y estas promesas hechas a Abraham (Gén 13,14-17; 17.4-8.16), repetidas luego a Isaac (Gén 26,3-6) y más tarde también a Jacob (Gén 28,13-15), fueron principalmente tres: La promesa de un heredero, una herencia y una descendencia numerosa; la promesa de establecer unas relaciones nuevas con aquella descendencia; $y$ la promesa de una tierra generosa y fecunda donde reposar. Cumplimiento de la primera promesa, que se verifica en Egipto, donde los clanes patriarcales se convierten en un pueblo numeroso y fuerte (Ex 1,7; 12,37-38; Deut 1,10; Neh. 9,23); la segunda se cumple en el Sinaí, donde Yavé pacta con los clanes salidos de Egipto una alianza de fidelidad (Ex cc. 19-24); y la tercera se cumple con la entrada del pueblo de Dios en la tierra de Canaán, bajo Josué (Jos $11,23)$. Sobre todo lo cual va discurriendo profusa y profundamente Von $\operatorname{Rad}{ }^{61}$.

Con el Pentateuco concluye la historia patriarcal; la esclavitud de los hijos de Israel en Egipto, a los que el Dios salvador de Abraham, Isaac y Jacob visita en sus padecimientos; la gesta grandiosa del Éxodo - al frente de Moisés, el Salvador - que constituye la intervención salvífica por antonomasia de la Antigua Alianza y cuya resonancia es comparada a la que para el Nuevo Testamento tiene la muerte y la resurrección de Cristo; el pacto del Sinaí, que señala el nacimiento del pueblo de Dios y el origen de una serie de instituciones legales, sociales y religiosas que prefiguran - de una manera velada - al tiempo que preparan las realidades de la Nueva Alianza; la peregrinación por el desierto hacia el descanso en el país de promisión; y, finalmente, la conquista y el asentamiento de Israel en la tierra prometida. Todo en aquel arco de

60. LAMAdrid, A.G.- ArNaldich, L., op. cit., p. 34.

61. Von RAD, G., Teología del Antiguo Testamento, vol. I, pp. 167-177. Edición preparada por Luis Alonso Schökel. Ediciones Sígueme, Salamanca 1972. Traducción del alemán por Victorino Martín Sánchez. 
tensión que articula la Historia de la Salvación, con la mirada fija en el heredero que nos la traerá definitivamente y en la tierra nueva a que Él nos llevará, donde no existe el llanto, ni la muerte, ni la guerra (Apoc 21,4).

Con los Jueces - aquellos hombres carismáticos impulsados por el espíritu de Yavé para la liberación- sigue desarrollándose la historia de Israel, al tiempo que la de la Salvación va avanzando hacia su realización en Cristo. Siguen los Reyes, entre los que destaca David, el rey según el corazón de Dios y con categoría para salvar a Israel, porque sobre él reposa el espíritu de Yavé (1Sam 16,13), y una de las figuras que la Biblia nos transmite con mayor simpatía y cariño ${ }^{62}$. Su elección viene ya marcada con el signo del misterio dívino en el ámbito de los criterios que Dios sigue para la elección de sus colaboradores en el avance de la salvación, tan contrarios a los criterios de los hombres. Y su acción liberadora y unificadora le hacen ser el prototipo del futuro Ungido, quien aglutinará en torno de su imperio a todas las tribus, pueblos y gentes de la tierra.

Con David, la alianza de Dios con su pueblo en el Sinaí, sin perder su carácter general, se concreta y se encarna en una familia, de la que saldrá el ReyMesías, Cristo (Mt 1,1.20; Lc 1,27.32), cuya acción salvífica será una intervención liberadora y definitiva para el pueblo de Dios, pero con marchamo ya de transcendencia y no centrada en un reino efímero y terreno (Jn cc. 18 y 19). Que la muerte, resurrección y ascensión de Cristo constituyen su entronización por Dios a su derecha como Rey (Act 2,22-36; Fil 2,5-11), aunque este reino - instaurado ya- espera aún su consumación definitiva en la Jerusalén celestial, donde Dios ha fijado su trono para siempre (1Cor 15,23ss; Col 3,1; Apoc 22,4-5) ${ }^{63}$.

Con la intervención de los profetas en la historia de Israel, la Historia de la Salvación se profundiza y se proyecta más hacia Cristo. Los profetas, predicando, sí, pero sobre todo hablando en lugar de Dios, se convierten en los intérpretes de la historia, juzgando los acontecimientos actuales a la luz de Dios, en una retrospección al pasado, en el que estaba patente la intervención de Dios, aclarando que también los hechos presentes son salvación, juicio, elección y creación en manos de aquel Dios que tanto amó a Israel - hasta el delirio - y al que Israel pagó - casi siempre - con indiferencia e infidelidad, y

62. Act 13,22, donde san Pablo - en su predicación a los judios de Antioquía de Pisidiaalude literalmente a los textos bíblicos de mayor resonancia histórica y salvífica de David, como haberse en él buscado Dios un hombre según su corazón para hacerle caudillo de su pueblo (1Sam 13,14); como haberle ungido Dios con su óleo santo para hacerle servidor suyo y servidor de su pueblo (Salm 89,21); como haberle Dios nombrado su pastor y pastor de su pueblo en el cumplimiento de todos sus deseos (Is 44,28).

63. RubIo MoráN, L., op. cit., pp. 173-182. 
anunciando incesantemente la instauración del reino de Dios por obra del Mesías prometido y futuro (Is 7,11 y 40 a 48; Jer 30 a 33; Os 14; Miq 4 a 5; Sof 3,9-20; Zac 9 a 14). Mesías prometido que traerá la salvación perfecta en la que los males profundos, que esclavizan al hombre, serán definitivamente superados, inaugurándose entonces una era de paz y de justicia, de amistad con Dios y felicidad, donde esté ausente todo el mal, bajo el que la humanidad doliente va gimiendo. Mesías prometido, cuyo reino no será sólo Israel sino todas las naciones a las que él someterá por los lazos del amor y no por la fuerza de las armas (Is 2,4). Y Mesías prometido, que será mediador de la nueva alianza con Dios, rota por la infidelidad del pecado, tomando Él la forma de siervo, de esclavo - «el Siervo de Yavé»- quien carga con los pecados del pueblo, y se ofrece a Dios por ellos. Por lo que Dios se complacerá en Él, y, en base a su propio sacrificio, le hará jefe de su reino, convirtiéndose - una vez más- la dorrota en camino de victoria y la muerte en sendero de triunfo y de exaltación (Is 52,13 y 53,12$){ }^{64}$.

En el ámbito profético de Israel ocurre y se encuadra el Destierro de Babilonia con sus tres etapas, las que coinciden con otras tantas rebeliones contra Nabucodonosor. Destierro de Babilonia que se convierte en el crisol de la fe para Israel, cuando - humanamente hablando- la destrucción de Jerusalén es el fin de sus esperanzas y el derrocamiento del trono de David. Y el corazón angustiado del pueblo en el exilio echa entonces en cara a Jeremías el silencio de su Dios, al que han vencido los dioses extraños. Aquellos dioses extraños, a los que los profetas calificaron tantas veces de vanidad y de falsía (Jer 44,18). Pero la desgarradora crisis de fe, que importa el Destierro, vuelve a encontrar en el propio Jeremías al principio, en Ezequiel durante el mismo destierro, y en el segundo Isaías al final del mismo, el sentido que para Israel entrañaba la deportáción, como anuncio y amenaza a la infidelidad a Yavé, como causa del castigo a esa infidelidad del pueblo y de sus reyes a la alianza, y como castigos y purificación - al mismo tiempo- a las desviaciones de su fe. Profetas - comenta san Agustín- a los que Dios «enviaba cuando le placía, bien para anunciar lo que era necesario, bien para corregir los pecados y encomendar la justicia» ${ }^{65}$.

$\mathrm{Y}$ es entonces cuando, junto a este aspecto de juicio, los profetas descubren al pueblo el sentido positivo que el Destierro encubre por los caminos de la Historia de la Salvación, requiriendo una conversión, que es como una resurrección de entre los muertos (Ez 37; Jer 31,31-34); una nueva toma de conciencia sobre la misión de Israel, misionero en el mundo (Is 43,10); y una nue-

64. Rubio MORÁN, L., op. cit., pp. 185-201.

65. San Agustin, De Civ. Dei, lib. XVII, 23. 
va iluminación sobre la problemática legal de la retribución (Ez 18,1-23) y sobre el sentido expiatorio del dolor. Función redentora del dolor, que expresará todo su enorme contenido y su profunda claridad en la profecía del Siervo de Yavé. Y así, toda la historia del Destierro se convierte en una prospección y en un acatamiento beneficioso a los planes de la Historia de la Salvación en y por Cristo: En aquel personaje humilde, cuya misión salvífica es universal y dolorosa por todos los caminos del dolor más agobiante (Is 49,1-6; 50,6; 53,1-3). Hasta tal punto que no va a la cruz forzado, sino que acepta y se ofrece a la muerte, libre y cariñosamente, como un servicio al pueblo, en su sustitución y en su beneficio total, tomando sobre sí la maldición que pesaba sobre el pueblo -debida a su pecado-, sufriendo Él el castigo que libera al pueblo, obrando la paz del siervo con Dios, y viéndose - por ello- ensalzado y puesto muy alto, como centro de atracción de todas las gentes, como su herencia y su pastor ${ }^{66}$.

Con la vuelta del Destierro de Babilonia, releyendo las palabras de los profetas anteriores y escuchando las de los que aún hablan al pueblo en nombre y en la persona de Yavé, los repatriados descubren que su empresa de reconstrucción empalma con la historia salvífica anterior: Ellos forman el «resto» predicado por los profetas pasados, el «resto» continuador de la promesa de Dios sobre su pueblo, el «resto» que es instrumento de salvación para el mismo pueblo y para las naciones. $Y$ de esta forma el designio de salvación de Dios continúa. La vuelta del Destierro ha sido como un nuevo «éxodo». Dios mismo es el que guía a los repatriados, realizando ahora - al igual que entonces- los más maravillosos prodigios, si bien no abriendo ya caminos en el mar, sino creando ríos en el desierto, por donde el «resto» retorna a la patria prometida (Is 43,19-20). Y, con la reconstrucción del templo y la reforma de Esdras y Nehemías, la comunidad adquiere su personalidad característica, no ya como pueblo o nación, sino - fundamentalmente- como una comunidad religiosa. A pesar de la corrupción interna que amenazaba con absorber a los repatriados en las olas encrespadas del paganismo circundante, contra lo que se alza la recriminación constante del profetismo, al tiempo que se insiste en la liberación por medio del ángel futuro y en la salvación del día de Yavé (Mal 1,3). Día que es el día del juicio del Señor —comenta san Agustín, el gran hermeneuta de la historia-, no siendo «extraño que se llame ángel del Señor omnipotente a Jesucristo. Pues como se le llamó siervo por la forma de siervo que tomó, así se le llama ángel por el Evangelio que anunció a los hombres. Porque Evangelio, traducido a nuestro idioma, es igual que buena nueva, y ángel es igual a nuncio» ${ }^{67}$.

66. Rubio MoRÁN, L., op. cit., pp. 205-225.

67. San Agustín, De Civ. Dei, lib. XVIII, 35,3. 
Y serán los sacerdotes, los escribas y los sabios como guías de aquella comunidad religiosa y como los mensajeros de Dios, que, al tiempo que al pueblo redescubren las gestas salvíficas pasadas siempre en manos de Yavé, y le instruyen la presencia actual de Dios sobre ellos, y constantemente le aseguran la intervención del Señor en favor de su pueblo por la palabra y por el culto, a la comunidad preparan para el advenimiento de la Palabra definitivamente salvadora y del sacrificio redentor y universal de Cristo. Cristo, de quien son figura precursora los «pobres de Yavé». Esos «pobres de Yavé», que son como el alma de la comunidad, precisamente por haber sabido mantener firme y pura la esperanza de la salvación de Dios, sin mezclarla con ambiciones materiales o nacionalistas; esos "pobres de Yavé», por los que la espera de la salvación penetra en el Nuevo Testamento en la proyección de una salvación, tal como Dios la envía y quiere, y por caminos tan distintos de los que el pueblo sueña; esos «pobres de Yavé», que lo son - no tanto por no tener riquezas materiales - sino por su actitud religiosa de entrega plena y confiada en las manos de Dios, de quien únicamente nos puede venir la salvación segura, aunque los caminos que Él escoja para ello nos sean desconcertantes e incomprensibles. Como ocurrió con Cristo: Auténtico Siervo y Pobre de Yavé, que se entregó plenamente a Dios por la salvación de sus hermanos, habiendo sentido toda la indigencia de la condición humana - hasta la suprema- cual fue el abandono de Dios en la muerte y muerte de cruz ${ }^{68}$.

De esta manera, la Historia de la Salvación que se define - según hemos dejado ya apuntado- por la serie de intervenciones salvíficas de Dios en la historia de los hombres ${ }^{69}$, tras las múltiples intervenciones de la Antigua Alianza y en tensión continua hacia la intervención más profunda en y por Cristo, en Cristo se nos revela la plenitud. Pues en Él está la salvación, ya que ningún otro nombre nos ha sido dado bajo el cielo, por el que podamos ser salvos (Act. 4,12), en gracia a su crucifixión y a su resurrección de entre los muertos (Act 4,10), por lo que Dios le hizo Señor y Mesías (Act 2,36). «Ël, para evidenciar su divinidad - nos resume Agustín - obró muchos milagros. De ellos los Evangelios recogieron algunos, los suficientes para probar su intento, siendo el primer milagro su admirable nacimiento, y el último, su gloriosa ascensión al cielo con su cuerpo resucitado" ${ }^{70}$.

Cristo - Dios y hombre verdadero- que, perteneciendo a nuestra raza, es consanguíneo de la humanidad entera, a quien nada de lo humano es extrano excepto el pecado, hasta no avergonzarse de llamarnos sus hermanos (Heb.

68. RUBIo MORÁN, L., op. cit., p. 237.

69. Cfr. supra con referencia a nota 51 .

70. San Agustín, De Civ. Dei, lib. XVIII, 46. 
2,11). Pertenencia a la humanidad que capacita a Crisıo para su tarea salvadora, mostrándose como profeta y actuando como profeta, pero cuya actividad desborda absolutamente la categoría de los profetas; pues no sólo anuncia la venida del reino de Dios, sino que lt dice ya venido (Mt 11,12 y 12,32; Lc 17,21 y 23,42-43). Admitiendo ser el hijo de David, pero orientando las promesas hechas a David y en Él cumplidas hacia un origen más alto y más misterioso (Mt 22,41-46). Admitiendo, igualmente, ser el Mesías prometido y Rey, pero corrigiendo su esencia política y terrena, para centrarla en un carácter espiritual, interno y transcendente. Admitiendo y autodenominándose como Hijo del Hombre (Mt 24,29-31; Mc 14,62; Lc 22,66-71), pero juntando en sí mismo las dos ideas contradictorias que el judaísmo se había forjado del Mesías: El Siervo de Yavé, humillado y sufrido y el Hijo del Hombre, celeste y glorioso. Todo ello, en la plenitud del misterio cristiano y en la culminación de su misión salvífica por y en gracia de su única Persona divina, en el misterio de sus dos naturalezas íntegras, cabales y perfectas. Que el que, llevado de un anhelo de hacer el cristianismo más aceptable, suprima o reduzca - de cualquier modo que sea- la paradoja, el misterio que encierra el Jesús de Nazaret, no es fiel a la historia, ni fiel tampoco a la palabra de Dios ${ }^{71}$.

$Y$ a fe que ese querer sustituir una cristología «desde arriba» por una cristología «horizontal» ha llevado - no hace mucho- a algunos teólogos connotados a renovar errores cristológicos $-\mathrm{y}$ consecuentemente trinitariosque parecían ya superados en la teología. Han querido ensayar una cristología dinámico-funcional, dentro de una estructura vital y solidaria, para hacer más enfática y moderna la Historia de la Salvación. Como si la fórmula de Calcedonia - con aquella carga ontológica de una persona y dos naturalezas - no pudiese ser enmarcada en la historia de nuestra salud, y nuestra fe en el hombre Jesús fuese contraria al Dios que se hace visible en el hijo de María. Como si la persona de Cristo - en su dimensión terrena- marginase las pervivencias de la divinidad. Errores cristológicos que, al negar la preexistencia de Cristo como Hijo de Dios, al negar la noción de una persona en Cristo, engendrada desde la eternidad según la naturaleza divina, y en el tiempo, de la Virgen María según la naturaleza humana; $y$ al negar la idea de una naturaleza humana asumida por la Persona eterna de Verbo de Dios, afirmando la existencia de una persona humana en la que Dios se manifiesta, fueron condenados en una declaración de la Sagrada Congregación para la doctrina de la fe, aunque sin decir el nombre de los tres connotados teólogos holandeses ${ }^{72}$. Errores que el

71. RUBio MORÁN, L., op. cit., p. 307.

72. Ecclesia: Órgano de la Acción Católica Española, en su núm. 1585, pp. 7-10, Madrid 25 marzo-1 de abril de 1972, transcribe y publica «La Declaración para salvaguardia de la fe, en torno a algunos errores recientes sobre los misterios de la Encarnación y de la Santísima Trinidad». 
P. Luis Arias analiza en un profundo artículo de sana teología, al tiempo que nos da los títulos originales de las tres disquisiciones que motivaron la Declaración, así como los nombres de los teólogos en referencia - Holsbosch, Schillebecckc y Schoonenberg- y también el documento de la Congregación ${ }^{73}$.

Por su parte, también otras revistas de teología se hicieron eco del suceso, aunque quizá no tan apasionadamente como el P. Arias, porque de todo hay en la viña del Señor ${ }^{74}$. Por ello, no entraremos aquí en más pormenores, aunque sí nos place subrayar la verdad de Cristo, verdadero Dios y verdadero hombre, con un texto clásico de San Agustín: «Quien hizo al hombre, se hizo lo que hizo, para que no pereciera lo que hizo. Mas en tal forma se hizo hijo del hombre que siguió siendo Hijo de Dios. Hízose, por tanto, hombre, asumiendo lo que no era, sin perder lo que era; permaneciendo Dios, hízose hombre. Tomó tu yo, sin quedar absorbido por tu yo»" ${ }^{75}$.

Y tampoco abundaremos más aquí sobre la realización por Cristo de la Historia de la Salvación, y de su aplicación y expansión en y por la Iglesia, en espera de su consumación al final de los tiempos, acerca de lo que también algo dejamos apuntado más arriba. Pero sí queremos resaltar, al respecto, cómo toda la Historia de la Salvación gira en torno a dos centros de interés, que son el Sinaí y el Cenáculo ${ }^{76}$. Que si la primera de esas dos intervenciones fundamentales de Dios en la historia nos dice de la alianza de Dios - por medio de Moisés - con la descendencia de Abraham, dando origen a Israel como pueblo de Yavé, la segunda es la alianza de Dios con toda la humanidad -en y por el Hijo- dando origen al nuevo pueblo de Dios, a la Iglesia, en un anticipo sacramental de la alianza del Calvario. Dos intervenciones fundamentales de Dios en la Historia de la Salvación, en torno a las que surge —-según Rubio Morán - toda esa literatura dispar y divina que constituye la palabra de Dios, que es la Biblia, desde los orígenes de ese pueblo con el Génesis, hasta el Apocalipsis, en espera de la consumación definitiva y gloriosa del nuevo pueblo de Dios ${ }^{n}$.

Historia de la Salvación - finalizamos con Ratzinger- que se concentra, de algún modo, en el punto cúspide de la Pascua definitiva, clave de su interpretación y su foco iluminador. Porque es en este momento cuando se hace manifiesto que toda la historia es un éxodo, una salida. Desde la salida de Abraham de su pueblo, ànte la llamada de Yavé, hasta la salida de Cristo en

73. ARIAS, L., «Errores cristológicos y trinitarios recientes», en la revista Agustiniana Religión y Cultura, vol. 18, n. 71, septiembre-diciembre 1972.

74. Selecciones de teología, vol. 11, n. 42, pp. 168-182, abril-junio de 1972.

75. SAn Agustín, Serm. 127, n. 9 .

76. Ex 19 y 34; Mt 26,26-29; Mc 14,22-25; Lc 22,19-20; 1Cor 11,23ss.

77. RuBio MoRÁN, L., op. cit., p. 24. 
su resurrección con el «me voy y vuelvo a vosotros» (Jn 14,28). Con lo que sí puede y debe entroncarse la teología de la existencia, en el sentido más literal de la palabra: «ex-sistere», salida del hombre de sí mismo en la fe y en el amor de Cristo, base de toda la historia de la antigua alianza de Dios con los hombres ${ }^{78}$.

De todo lo cual se deduce que Cristo es el centro de la Biblia y es el centro del dogma, es el centro de la humanidad y es el centro de la vida, es el centro de la cultura y es el centro de la historia.

Centro de la Biblia, porque toda la Biblia mira a Cristo como encarnación de las continuas intervenciones salvíficas de Dios. Y ello, desde los primeros vagidos del paraíso, que no son más que un suspiro y un anhelo de redención y - por tanto- de Cristo Redentor, pasando por los anuncios fulgurantes de los profetas del Antiguo Testamento, hasta llegar a su vida entre los hombres, cuando lleva a cabo nuestra salvación al precio de su sangre, según el designio salvífico de Dios, y la perfecciona en la Iglesia, como prolongación del mismo Cristo, que actualiza hoy la salvación de los hombres por medio de la comunidad que Él dejó sobre la tierra, como manifestación viviente y visible de la salvación por Él realizada. En espera de su consumación gloriosa al final de los tiempos. Que Jesús de Nazaret - acota al efecto Rubio Moránes y constituye el centro de la salvación... y toda la balbuciente espera de la humanidad - anterior o externa al pueblo elegido - halla también en él su realización. Pero Él no ha pasado. Continúa vivo, presente, actual, siendo también hoy la fuente de la salvación. El, ayer, hoy y por los siglos. Él, el principio y el fin, el alfa y el omega en el orden de la salvación ${ }^{79}$.

De donde hasta la teología es y debe ser cristocéntrica, haciendo valer acertadamente la posición central de Cristo en la historia de la creación, en la historia de la salvación y en la historia de nuestra consumación beatífica. Verdad es que el centro objetivo, la raíz y la cúspide de todo el orden sobrenatural es el Dios, Uno y Trino. Es el único misterio formal de Dios, que viene dado en todo aquello que la dogmática cristiana proclama como misterios del cristianismo, según dejamos ya apuntado ${ }^{80}$. Pero Cristo es el misterio de Dios revelado, es la Sabiduría de Dios encarnado; de ahí que toda nuestra ciencia teológica - subraya Scheeben - está unida por todas partes con la Sabiduría personal encarnada de Dios; está en proporción con ella y, por esto, recibe también de la misma su rúbrica peculiar divino-humana. Que del seno de la Trinidad salió Cristo mismo y a ese mismo seno vuelve con su cuerpo místico; pero

78. RATZINGER, J., Teología e historia, pp. 67-69.

79. Rubio MORÁN, L., op. cit., p. 242.

80. Cf. supra capítulo I, con referencia a nota 2 . 
mientras vamos caminando hacia él y hayamos de ver lo invisible en lo visible, nuestra sabiduría teológica - por ser simultáneamente humana y divina- debe apegarse, ante todo, a este lado humano de Cristo, para poder ascender a su lado divino, a su unidad con el Padre ${ }^{81}$.

Cristo lo es todo para el hombre, y lo es todo para la humanidad. Él es el nuevo Adán que da la vida al género humano; Él es el Redentor que nos libró de nuestra caída; Él es el único y verdadero mediador. Desde las lejanías del paraíso, Cristo era visto como el futuro dominador, el que había de librar a la humanidad - rota y desgarrada - del profundo abismo en que yacía. Y la historia viró así hacia Cristo. Y Cristo, al aceptar su Encarnación, aceptó el más transcendental de los deberes: Dar un nuevo ser a las cosas, a los hombres, a la humanidad. Se diría que aceptó ser el Creador del hombre nuevo. Y, con la creación del hombre nuevo, Cristo se convirtió en el centro de la cultura y de la vida. Pues, si el primer dogma y el más fundamental de la cultura de la vida debe ser una creencia robusta del alma en el más allá, Cristo nos enseñó - con palabras y con obras - que la vida carece de sentido en sí misma, como las andanzas de un viajero. Hay que anclarla en una realidad última y definitiva, hay que orientarla de continuo hacia la eternidad, porque solamente lo que dura es siempre válido y lo perfecto, y lo que no es eterno nada vale. Por eso, al constituirse Cristo en nuestro camino, nuestra verdad y nuestra vida, se constituyó en el sendero asegurado de nuestra cultura - siempre en hambreos de divinidad-, en la verdad de nuestra eternidad y en la eternidad de nuestra vida, como incansablemente nos repite san Agustín ${ }^{82}$.

Hace un poco decíamos que desde los orígenes de la humanidad viró la historia hacia Cristo. Es verdad que quien desea interpretar la historia de Israel con ojos puramente racionales, sin tener para nada en cuenta el hecho de la tan esperada venida de Cristo, no la interpretará como es, porque Cristo es ciertamente uno de los ejes para la recta hermenéutica de la historia. Sin Cristo la historia es ininteligible. Precisamente el significado profundo de los hechos, narrados como pretéritos, en la historia anterior a Cristo, tiene el rostro totalmente vuelto a Cristo. La «prophetica historia» agustiniana ${ }^{83}$ es la demostración más palpable de que en torno a Cristo se desarrolla la historia antigua; pero también frente a Cristo se desarrolla la contemporánea a El, y sobre Cristo gira la posterior. Cristo es la conjunción de dos edades. Cristo es el lazo de unión, la intersección de dos coordenadas históricas, cuales son la Providencia de Dios y la lihertad humana ${ }^{84}$.

81. SCHEEBEN, M.J., Los misterios del cristianismo, p. 859.

82. SAN Agustín, Serm. 141, n. 4; 142, n. 2; Epist. 90, n. 5; 123, n. 2; 125, n. 2; Tract. in Jo. 13,4; De Cantico novo, 4 et passim.

83. San Agustín, De Civ. Dei, lib. X, 32,3; XII, X, 2; XVI, 2,3.

84. Cfr. supra, con referencia a nota 51 . 
Así, pues, la historia es un caos sin Cristo, porque Él es la luz que la ilumina. Y sírvanos esta anotación para entender el cristocentrismo agustiniano. Que san Agustín es, por esencia, cristocéntrico: Todo lo hace girar en torno a Cristo. Y, si el mundo antiguo y su historia es preludio de Cristo, a partir de la Encarnación la historia no puede comprenderse ya sin Cristo. Por lo que Cristo es un criterio de recta inteligencia e interpretación de los acontecimientos históricos. Ahí está para probarlo su Ciudad de Dios - quizás el mejor tratado que se haya escrito de política y sociología - en la que la política moderna tiene tanto que aprender, cuando busca la paz por caminos distintos y distantes de los que nos marcó la persona de Cristo y la luz de su mensaje.

Sociedad a la que todos los hombres tenemos que hacer más civilizada, sin confundir civilización con fastuosidad, ni felicidad con opulencia, sino llevando a ella la tranquilidad del orden con el orden de nuestro amor, que es la virtud. $\mathrm{Y}$ a fe que lo conseguiremos en la medida en que nosotros y ella nos hagamos más cristocéntricos, más cristianos. Pues la esencia del cristianismo es Jesucristo ${ }^{85}$, ya que en Él Dios se ha inclinado hacia la humanidad para elevarla hasta sí. Y toda otra cosa que pueda llamarse parte constitutiva del cristianismo - su doctrina, sus preceptos, su liturgia, sus sacramentos- solamente se dirá cristiana, en cuanto sea realización, exigencia o actualización de la Persona de Cristo. Pues no hay doctrina ética o culto cristiano que no se refiera a Él —nos rubrica Schmaus-: ya que la doctrina es actualización e interpretación de Cristo; la moralidad es imitación de Cristo, y el culto es participación en la glorificación que Cristo hace al Padre. Cristo lo es todo: Es el centro vital del que todo fluye y en el que todo desemboca ${ }^{86}$.

Y cristocentrismo que fue la bandera y el clarín de todo el Vaticano II, como muy claramente lo indican las terminantes palabras del papa Pablo VI en su alocución vibrante del 29 de septiembre de 1963, al abrir la segunda sesión del magno evento, y responder al triple interrogante sobre su punto de partida, su camino y la meta del transcendental itinerario: «Estas tres preguntas sencillísimas y capitales tienen, como bien sabemos, una sola respuesta... ¡Cristo! Cristo, nuestro principio, Cristo, nuestra vida y nuestro guía, Cristo, nuestra esperanza y nuestro término» ${ }^{87}$. Palabras que no son sino el eco de aquel clamor gigantesco del cristocentrismo agustiniano: «Mi origen es Cristo, Cristo es mi sustento, mi Cabeza es Cristo» ${ }^{88}$.

\section{Juan Manuel CUENCA COLOMA}

85. ADAM, K., El Cristo de nuestra fe, pp. 59-60. 3. ${ }^{a}$ ed. Editorial Herder, Barcelona 1966.

86. SchmaUs, M., Teología dogmática, vol. III, p. 117.

87. Pablo VI: Alocución del 29 de septiembre de 1963.

88. San Agustin, Contra Litteras Petiliani I, cap. 7, n. 8. 